\title{
Liver Fibrosis as a Predictive Factor of Response to Pegylated-IFN/ Ribavirin Therapy in Chronic HCV Patients
}

\author{
WAHID DOSS, M.D.*; MOHAMED ALI SABER, M.D.**; MOHAMMAD EL-SAYED, M.D.*; \\ AHMED EL DEEB, M.Sc.*** and GAMAL ESMAT, M.D.*
}

The Department of Endemic Medicine, Gastroenterology \& Tropical Hepatology, Faculty of Medicine, Cairo University*, Biochemistry \& Molecular Biology Department, Theodor Bilharz Research Institute** and National Hepatology \& Tropical Medicine Research Institute (NHTMRI)***

\begin{abstract}
Background: The stage of fibrosis is a sensitive predictor of sustained virological response to Pegylated INF/Ribavirin in chronic hepatitis $\mathrm{C}$.

Aim of Study: To assess the value of liver fibrosis as a predictor of SVR.

Patients and Methods: This study was a retrospective controlled study and was performed on a total number of 240 patients who were treated by PEG-IFN alpha/RBV for 48 weeks and fibrosis stage was done for the all patients.

Results: SVR was significant high in patients with F0 and F1 fibrosis stage.

Conclusion: The fibrosis stage was a strong pretreatment predictor of response to pegylated interferon and ribavirin therapy in egyptian patients chronically infected with HCV genotype 4.
\end{abstract}

Key Words: HCV-Pegylated Interferon - Liver fibrosis.

\section{Introduction}

CHRONIC hepatitis C virus (HCV) infects approximately 170 million people worldwide, is a major cause of chronic hepatitis, liver cirrhosis and hepatocellular carcinoma and represents the most frequent cause for liver transplantation in the US and Europe [1], Moreover, the incidence of chronic liver failure secondary to HCV-related liver cirrhosis is expected to increase over the next 10 years as a result of the 'silent epidemic' of HCV infection [2].

Pegylated interferon (PEG-INF) plus ribavirin (RBV) therapy given for 48 weeks is now estab-

Correspondence to: Dr. Wahid Doss, The Department of Endemic Medicine, Gastroenterology \& Tropical Hepatology, Faculty of Medicine, Cairo University lished as the standard therapy for patients with chronic HCV infection with genotypes 1 and 4 [3]. This treatment has yielded overall sustained virological response (SVR) rates of $54 \%$ to $69 \%$ in randomized controlled phase III clinical trials $[4,5]$. However, response to treatment is not uniform across all populations [6] and is dependent on various viral and host factors.

Most of the studies conducted worldwide have included patients infected with HCV genotypes 1, 2,3 and $4[4,5,6]$. According to these studies, factors independently associated with body weight $<75 \mathrm{~kg}$, age younger than 40 years, an absence of pretreatment bridging fibrosis or cirrhosis, being treatment naïve, infection with HCV genotype 2 or 3 , and favorable initial virological response $[4,5,6,7]$.

The aim of this work was to assess the value of pre-treatment liver fibrosis stage as a predictor of virological response to Pegylated interferon plus ribavirin in treatment of chronic hepatitis $C$ virus Egyptian patients.

\section{Patients and Methods}

\section{Patients:}

This study was conducted on 240 Egyptian patients infected with HCV. Patients were selected from $\mathrm{HCV}$ clinics at the National Hepatology and Tropical Medicine Research Institute (NHTMRI) starting from January 2012 to October 2013.

The patients were treated with Pegylated Interferon $\mathrm{a} 2 \mathrm{~b}$ or $2 \mathrm{a}$ (PEG-IFN) plus ribavirin. Treatment duration was determined according to their response using quantitative PCR for $\mathrm{HCV}$ at the 
three, six months from the treatment starting. Patients who had decrease of viral load by more than two logs or undetectable viraemia or (by quantitative PCR) at third month from the start of treatment will continue treatment, while who didn't achieve those treatment endpoints had been discontinued treatment. Patients with any detected viraemia at sixth from the start of treatment had been discontinued treatment. All patients had signed an informed consent.

\section{Inclusion criteria:}

1- HCV positive patients aged 18 to 65 years old.

2- Elevated ALT level above the upper limit of normal within six months prior to the study.

3- Histological, laboratory and virological diagnosis of chronic HCV.

4- Patients had not been previously experienced treatment with interferon based anti-viral therapy.

\section{Exclusion criteria:}

1-Poorly controlled diabetes mellitus, hypertension, or psychiatric diseases.

2- Presence of ANA titre (antinuclear antibodies) $>1 / 160$.

3- Hemoglobin $<13 \mathrm{~g} / \mathrm{dL}$ for men and $<12 \mathrm{~g} / \mathrm{dL}$ for women, white blood cell count of $<3,000 / \mathrm{mm}^{3}$, absolute neutrophil count of $<1500 / \mathrm{mm}^{3}$, or platelet count of $<80,000 / \mathrm{mm}^{3}$.

4- Patients with hepatitis B surface antigen (HB$\mathrm{sAg}$ ) seropositivity or infected with the human immunodeficiency virus (HIV).

5- Thyroid stimulating hormone (TSH) out of normal range (0.5-5 International Units/l).

6- Decompensated liver disease.

7- Active schistosomiasis.

8- Serum creatinine above the upper limit of normal.

\section{Specimen collection:}

Early morning blood samples were collected; $8 \mathrm{ml}$ venous samples were withdrawn and divided into 2 tubes under aseptic conditions from patients and after obtaining their written consent as follows:

- Four ml blood on EDTA using a sterile tube, the EDTA samples were stored at $-80^{\circ} \mathrm{C}$ to be used for molecular biology techniques.

- Four ml blood were left for 10 minutes to clot and then centrifuged for 5 minutes. The serum was then separated for determination of all serological tests as well as HCV-RNA Quantitation.
Methods:

Laboratory tests:

I- Routine tests:

1-Liver biochemical profile: Serum bilirubin (total and direct), transaminases (ALT and AST), alkaline phosphatase, total protein, serum albumin and prothrombin time and concentration.

2- Complete blood picture.

II- Serological tests for chronic hepatitis markers:

a- Anti-HCV EIA: The third generation Abbott HCV EIA 3.0 was used (Abbott Laboratories, Ludwigshafen, Germany).

b- HBsAg EIA: According to Abbott Monoclonal EIA (Abbott Laboratories, Ludwigshafen, Germany).

c- Anti-HBc EIA: The Abbott CORZYME commercial assay for qualitative detection of antibodies to HBV core protein (IgG and IgM) was used (Abbott Laboratory, Ludwigshafen, Germany and Abbott Park, II).

\section{III- HCV RNA using real time quantitative PCR Technique:}

It was done for all patients to detect the viral load. Pretreatment PCR assessment then at 12 th, 24 th, 48 th and $72^{\text {th }}$ week from start of treatment.

\section{IV-Liver biopsy for histological assessment:}

Trans-abdominal ultrasound guided liver biopsy was done for all patients prior to starting treatment for $\mathrm{HCV}$ to assess grade of inflammation (Activity) and stage of fibrosis according to METAVIR scoring system. The stage of liver fibrosis was scored according to the METAVIR scoring system: F0 (no fibrosis), F1 (mild fibrosis: portal fibrosis without septa), F2 (moderate fibrosis: few septa), F3 (severe fibrosis: Numerous septa without cirrhosis) and F4 (cirrhosis). Inflammation was graded A0 (no activity), A1 (mild activity), A2 (moderate activity), A3 (severe activity).

\section{Statistical methods:}

Numerical data were expressed as mean and standard deviation. For quantitative data normally distributed, comparison between two groups was done using $t$-test. Comparison between three groups or more was done using ANOVA test.

Qualitative data were expressed as frequency and percentage. Chi-square test (Fisher's exact test) was used to examine the relation between qualitative variables.

For quantitative and qualitative data not normally distributed, comparison was done using 
Kruskal-Wallis test. Logistic regression model was done for predictors' detection at $95 \%$ confidence level. A $p$-value $<0.05$ was considered significant. Data was analyzed using PASW statistics 18.

\section{Results}

Table (1) shows all baseline demographic, histological and virological characteristics of the studied patients.

Table (1): Distribution of studied patients was according to their baseline characteristics.

\begin{tabular}{|c|c|c|}
\hline \multirow{2}{*}{ Variable } & \multicolumn{2}{|c|}{ Studied patients } \\
\hline & Number & Percent \\
\hline \multicolumn{3}{|l|}{ Age: } \\
\hline$\leq 40$ & 116 & 48.3 \\
\hline$>40$ & 124 & 51.7 \\
\hline Total & 240 & 100 \\
\hline Mean \pm SD & \multicolumn{2}{|c|}{$40.30 \pm 10.912$} \\
\hline \multicolumn{3}{|l|}{ Gender: } \\
\hline Male & 172 & 71.7 \\
\hline Female & 68 & 28.3 \\
\hline Total & 240 & 100 \\
\hline \multicolumn{3}{|l|}{ Degree of fibrosis: } \\
\hline Mild (F1) & 152 & 63.3 \\
\hline Moderate - severe (F2-F3) & 88 & 36.7 \\
\hline Total & 240 & 100 \\
\hline \multicolumn{3}{|l|}{ Degree of activity: } \\
\hline Mild (A1) & 152 & 63.3 \\
\hline Moderate - severe (A2-A3) & 88 & 36.7 \\
\hline Total & 240 & 100 \\
\hline
\end{tabular}

Statistically there was no significant correlation between response of chronic hepatitis $\mathrm{C}$ patients treated with Peg-IFN/RBV and age or gender with $p$-value (0.653) and (0.403) respectively.

The relation between the $\alpha$ feto protein $\&$ response to treatment was statistically non significant.

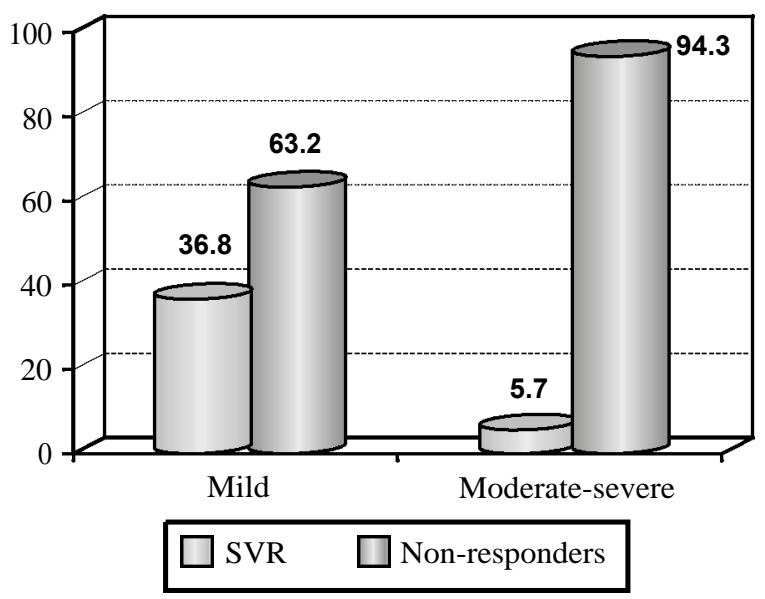

Fig. (1): Relation between response of chronic hepatitis $C$ patients treated with Peg IFN/RBV and degree of fibrosis.
As regard patients with mild fibrosis, $36.8 \%$ of patients (56 patients) had achieved SVR while $63.2 \%$ were non-responders (96 patients), while $5.7 \%$ of patients (5 patients) had achieved SVR and $94.3 \%$ were non-responders ( 83 patients) with moderate to severe fibrosis. The relation between the response of chronic hepatitis $\mathrm{C}$ patients treated with Peg IFN/RBV and degree of fibrosis was highly significant with $p$-value $(p<0.001)$.

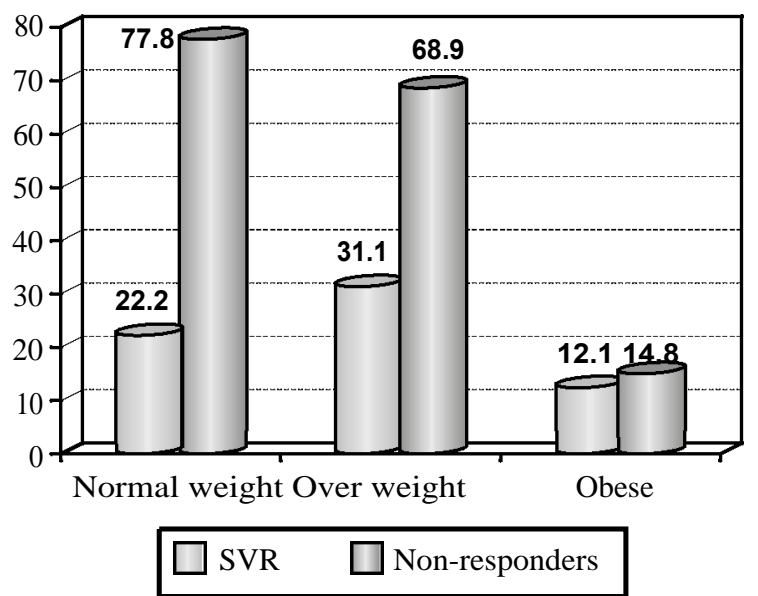

Fig. (2): Relation between response of chronic hepatitis C patients treated with Peg IFN/RBV and obesity (BMI).

In our study the relation between response of chronic hepatitis $\mathrm{C}$ patients treated with Peg IFN/RBV and obesity was statistically non significant with $p$-value (0.616) (Fig. 2).

Table (2): Predictive factors for response to Peg-INF/RIB by logistic regression model: Univariate analysis using a logistic regression model of predictive factors detection at $95 \%$ confidence level.

\begin{tabular}{lcc}
\hline Predictor & $95 \% \mathrm{CL}$ & Significance \\
\hline Degree of fibrosis & $0.205-0.426$ & $0.001(\mathrm{HS})$ \\
\hline
\end{tabular}

A $p$-value $<0.05$ was considered significant.

This model was performed to identify liver fibrosis stage that was associated with SVR to combination therapy with PEG INF/RIB.

The fibrosis stage was highly significant as predictors of response to treatment of patients with chronic HCV with $p$-value $<0.001$.

\section{Discussion}

Host factors including age, body weight, insulin resistance, stage of fibrosis, and compliance influence the outcome of antiviral treatment in patients with chronic HCV. Moreover, chronic HCV European or Asian patients have a higher rate of SVR 
than African American or Hispanic patients [6,7], reinforcing the influence of genetic host factors.

Our study reconfirmed the previously reported findings in various populations around the world in a large cohort of HCV mono-infected patients with chronic hepatitis C genotype (GT) 1 [8-11], but our study included Egyptian patients who are mainly infected with HCV GT4.

Stättermayer et al., observed that there was a difference in the impact of IL-28b polymorphism among viral genotypes (GTs) [12]. In contrast to GT1 and GT4 patients, the rs 12979860 SNP had no impact on SVR rates in GT2/3. They have reported associations of rs 12979860 CC genotype and rs8099917 TT genotype with RVR but not SVR in patients with HCV genotype $2 / 3$ infection, implying that the $\mathrm{CC}$ genotype may be associated with relapse in their population too.

Studies of HCV genotype 2-infected European patients show that the CC genotype at rs 12979860 can predict SVR, but this is largely driven by patients who do not achieve RVR [13] .

By studying other factors that may have relation to response to treatment, our study found that there was no significant relation between the age and the response to treatment ( $p 0.653$ ).

Also, the gender had no significant relation ( $p$ 0.403) while Stättermayer et al., (2011) found that age of patients had significant effect on the SVR to standard combination treatment for which younger patients had better SVR ( $p=0.003)$, however there was no significant correlation between sex and SVR [12]

Manns et al., [14] and Fried et al., [2] found that on univariate analyses a significant negative correlation between male gender and SVR was found in both Peg-IFN \& RBV trials, but no statistically significant correlation was found on multivariate analyses.

By assessing the response to treatment in relation to degree of inflammation and stage of fibrosis, patients with mild to moderate fibrosis (F1\&F2) had significant higher rates of SVR than patients with advanced fibrosis (F3-F4) (36.8\% vs $5.7 \%$, $p<0.0001$ ).

These findings agree with the result of Stättermayer et al., [12]; who found that patients with advanced fibrosis (F3 \& F4) had lower SVR than patients with mild to moderate fibrosis (F 1 \& F2) $(p=0.007)$.
Our study revealed that the relation between serum a feto protein and response to treatment was statistically non significant.

In contrast Abdoul, et al., [15] who examined the association between serum alpha-fetoprotein level and sustained virological response (SVR) in 93 chronic hepatitis $C$ patients, The SVR rate was higher among patients with serum AFP levels below rather than above the median value $(5.7 \mathrm{ng} / \mathrm{ml})$ (58.7\% and $19.2 \%$, respectively; $p=0.0001$ ). They recommend that serum AFP should be added to the list of factors predictive of treatment response in chronic HCV patients.

In our study the relation between response of HCV patients treated with peg IFN/RBV and obesity was statistically no significant with $p$-value ( $p$ $0.616)$.

In a prospective trial, a body mass index (BMI) of $>25 \mathrm{~kg} / \mathrm{m}^{2}$ was significantly associated with progression of fibrosis [16].

A high BMI was also inversely correlated with SVR in both IFN and PEG IFN treated individuals $[17,18]$

Moreover, in both, peg INF alfa-2a and peg IFN alfa-2b combination therapy with RBV, a lower baseline body weight $(<75-80 \mathrm{~kg}$ ) was significantly associated with achieving an SVR in all genotypes $[2,14,18]$

However, this finding was not confirmed in other large studies with peg INF/RBV combination therapy in HCV genotypes 1-3-infected patients in which multilogistic regression analyses including BMI and body weight were conducted $[19,20]$.

\section{Conclusion:}

Pretreatment Liver fibrosis stage was a strong predictor of response to Pegylated interferon and ribavirin in Egyptian patients chronically infected with HCV genotype 4.

\section{Author disclosure statement:}

No conflict of interest.

\section{References}

1- KAMAL S.M. and NASSER I.A.: Hepatitis C genotype 4: What we know and what we don't yet know. Hepatology, Apr. 47 (4): 1371-83. doi: 10.1002/hep.22127, 2008.

2- FRIED M.W1, SHIFFMAN M.L., REDDY K.R., SMITH C., MARINOS G., GONÇALES F.L. JR, HÄUSSINGER D., DIAGO M., CAROSI G., DHUMEAUX D., CRAXI A., LIN A., HOFFMAN J. and YU J.: Peginterferon alfa2a plus ribavirin for chronic hepatitis $\mathrm{C}$ virus infection. N. Engl. J. Med., Sep. 26; 347 (13): 975-82, 2002. 
3- GHANY M.G1, STRADER D.B., THOMAS D.L. and SEEFF L.B.: Diagnosis, management, and treatment of hepatitis C: An update; American Association for the Study of Liver Diseases. Hepatology, Apr. 49 (4): 1335 74. doi: 10.1002/hep.22759, 2009.

4- BROWN R.S. Jr.: Customizing treatment to patient populations. Nat. Clin. Pract. Gastroenterol. Hepatol., Jan. 4 (Suppl 1): S3-9, 2007.

5- ESMAT G1, EL RAZIKY M., ELSHARKAWY A., SABRY D., HASSANY M., AHMED A., ASSEM N., EL KASSAS M. and DOSS W.: Impact of vitamin D supplementation on sustained virological response inchronic hepatitis $\mathrm{C}$ genotype 4 patients treated by pegylated interferon/rib-avirin. J. Interferon Cytokine Res., Jan. 35 (1): 49-54. doi: 10.1089/jir.2014.0060, 2015.

6- YAN K.K1, GUIRGIS M., DINH T., GEORGE J., DEV A., LEE A. and ZEKRY A.: Treatment responses in Asians and Caucasians with chronic hepatitis $\mathrm{C}$ infection. World J. Gastroenterol., Jun. 7; 14 (21): 3416-20, 2008.

7- MUIR A.J1, BORNSTEIN J.D. and KILLENBERG P.G.: Atlantic Coast Hepatitis Treatment Group. Peginterferon alfa- $2 b$ and ribavirin for the treatment of chronic hepatitis $\mathrm{C}$ in blacks and non-Hispanic whites. N. Engl. J. Med., May 27; 350 (22): 2265-71, 2004.

8- GONZALEZ S.A1 and KEEFFE E.B.: IL-28B As a Predictor of Sustained Virologic Response in Patients with Chronic Hepatitis C Virus Infection.Gastroenterol. Hepatol. (N Y), Jun. 7 (6): 366-73, 2011.

9- SUPPIAH V1, MOLDOVAN M., AHLENSTIEL G., BERG T., WELTMAN M., ABATE M.L., BASSENDINE M., SPENGLER U., DORE G.J., POWELL E., RIORDAN S., SHERIDAN D., SMEDILEA., FRAGOMELI V., MÜLLER T., BAHLO M., STEWART G.J., BOOTH D.R. and GEORGE J.: IL28B is associated with response to chronic hepatitis $\mathrm{C}$ interferon-alpha and ribavirin therapy. Nat. Genet., Oct. 41 (10): 1100-4, 2009. doi: 10. 103 8/ng.447. Epub 2009 Sep 13.

10- THOMPSON A.J1, MUIR A.J., SULKOWSKI M.S., GE D., FELLAY J., SHIANNA K.V., URBAN T., AFDHAL N.H., JACOBSON I.M., ESTEBAN R., POORDAD F., LAWITZ E.J., McCONE J., SHIFFMAN M.L., GALLER G.W., LEE W.M., REINDOLLAR R., KING J.W., KWO P.Y., GHALIB R.H., FREILICH B., NYBERG L.M., ZEUZEM S., POYNARD T., VOCK D.M., PIEPER K. S., PATEL K., TILLMANN H.L., NOVIELLO S., KOURY K., PEDICONE L.D., BRASS C.A., ALBRECHT J.K., GOLDSTEIN D.B. and McHUTCHISON J.G.: Interleukin-28B polymorphism improves viral kinetics and is the strongest pretreatment predictor of sustainedvirologic response in genotype 1 hepatitis $\mathrm{C}$ virus. Gastroenterology, Jul. 139 (1): 120-9.e18, 2010. doi: 10.1053/j.gastro.2010. 04.013. Epub 2010 Apr 24.

11- TOYODA H1, KUMADA T., TADA T., KAWAGUCHI T., MURAKAMI Y. and MATSUDA F.: Impact of genetic polymorphisms near the IL28B gene and amino acid substitutions in the hepatitis $\mathrm{C}$ virus coreregion on interferon sensitivity/resistance in patients with chronic hepatitis C. J. Med. Virol., Jul. 83 (7): 1203-11, 2011. doi: 10.1002/jmv.22092.
12- STÄTTERMAYER A.F1, STAUBER R., HOFER H., RUTTER K., BEINHARDT S., SCHERZER T.M., ZINOBER K., DATZ C., MAIERON A., DULIC-LAKOVIC E., KESSLER H.H., STEINDL-MUNDA P., STRASSER M., KRALL C. and FERENCI P.: Impact of IL28B genotype on the early and sustained virologic response in treatment-naïve patients with chronic hepatitis C. Clin. Gastroenterol. Hepatol. Apr. 9 (4): 344-350.e2, 2011. doi: 10.1016/j.cgh.2010.07.019. Epub 2010 Aug 20.

13- MANGIA A., THOMPSON A.J., SANTORO R., et al.: An IL28B polymorphism determines treatment response of hepatitis $\mathrm{C}$ virus genotype 2 or 3 patients who do not achieve a rapid virologic response. Gastroenterology, 139: 821-7, 2010.

14- MANNS M.P1, McHUTCHISON J.G., GORDON S.C., Rustgi V.K., SHIFFMAN M., REINDOLLAR R., GOODMAN Z.D., KOURY K., LING M. and ALBRECHT J.K.: Peginterferon alfa- $2 b$ plus ribavirin compared with interferon alfa-2b plus ribavirin for initial treatment of chronic hepatitis C: A randomised trial. Lancet, Sep. 22; 358 (9286): 958-65, 2001.

15- ABDOUL H1, MALLET V., POL S. and FONTANET A.: Serum alpha-fetoprotein predicts treatment outcome in chronic hepatitis $\mathrm{C}$ patients regardless of $\mathrm{HCV}$ genotype. PLoS One, Jun. 11; 3 (6): e2391. doi: 10.1371/journal. pone.0002391, 2008 .

16- ORTIZ V1, BERENGUER M., RAYÓN J.M., CARRASCO D. and BERENGUER J.: Contribution of obesity to hepatitis C-related fibrosis progression. Am. J. Gastroenterol., Sep. 97 (9): 2408-14, 2002.

17- BRESSLER B.L1, GUINDI M., TOMLINSON G. and HEATHCOTE J.: High body mass index is an independent risk factor for nonresponse to antiviral treatment in chronic hepatitis C. Hepatology, Sep. 38 (3): 639-44, 2003.

18- BERG T1, VON WAGNER M., NASSER S., SARRAZIN C., HEINTGES T., GERLACH T., BUGGISCH P., GOESER T., RASENACK J., PAPE G.R., SCHMIDT W.E., KALLINOWSKI B., KLINKER H., SPENGLER U., MARTUS P., ALSHUTH U. and ZEUZEM S.: Extended treatment duration for hepatitis $\mathrm{C}$ virus type 1 : Comparing 48 versus 72 weeks of peginterferon-alfa-2a plus ribavirin. Gastroenterology, Apr. 130 (4): 1086-97, 2006.

19- ZEUZEM S1, HULTCRANTZ R., BOURLIERE M., GOESER T., MARCELLIN P., SANCHEZ-TAPIAS J., SARRAZIN C., HARVEY J., BRASS C. and ALBRECHT J.: Peginterferon alfa- $2 b$ plus ribavirin for treatment of chronic hepatitis $C$ in previously untreated patients infectedwith HCV genotypes 2 or 3. J. Hepatol., Jun. 40 (6): 993-9, 2004.

20- JACOBSON I.M1, BROWN R.S. Jr., FREILICH B., AFDHAL N., KWO P.Y., SANTORO J., BECKER S., WAKIL A.E., POUND D., GODOFSKY E., STRAUSS R., BERNSTEIN D., FLAMM S., PAULY M.P., MUKHOPADHYAY P., GRIFFEL L.H. and BRASS C.A.: WIN-R Study Group. Peginterferon alfa-2b and weight-based or flat-dose ribavirin in chronic hepatitis $\mathrm{C}$ patients: A randomized trial. Hepatology, Oct. 46 (4): 971-81, 2007. 


\section{استخدام درجة التليف فى النسيج الكبدى قبل العلاج

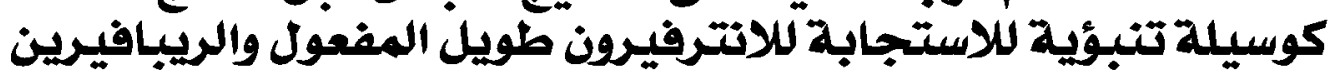

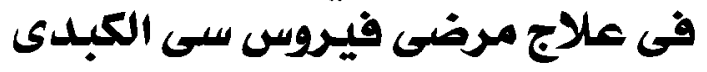

الخلفية": المرضي من ذوى درجات التليف البسيطة من الدرجة صفر أو ا يحققن غالباً الاستجابة الجيدة والعالية للعلاج بعقارى الانترفيرون طويل المفعول وكبسولات الريبافيرين لمرضى فيروس في سلى المزمن النثط. الهدف من العمل : تقيّم درجة التليف فى النسيج الكبدى قبل العلاج كمتبئ لـ للاستجابة للعلاج بعقارى الانترفيرن طويل المفعول وكبسولات

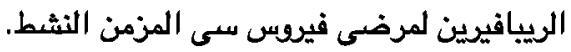

المرضنى والطرق: هذه الدراسة عبارة عن دراسة بآثر رجعى تم إجراؤها على إجمالى .عن مريضاً تم علاجهم بعقارى الانترفيرنن طويل

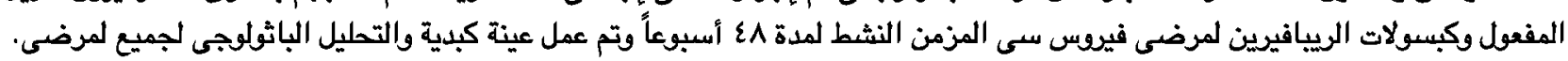
النتائج: كان درجات التليف البسيطة صفر و ا هم أكثر انتشاراً فى مجموعة المرضى المستجيبين أكثر من درجات التيف الأعلى الخلاصة

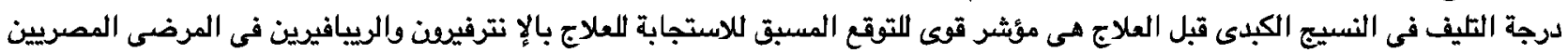
المصابين بفيروس سى المزمن النشط. 